\title{
Effect of Nitriding on the Microstructure and Mechanical Properties of Stainless Steels
}

Petr Faltejsek, Zdeněk Joska, Zdeněk Pokorný, David Dobrocký, Zbyněk Studený

Department of Mechanical Engineering, Faculty of Military Technology, University of Defence, 66210 Brno, Czech Republic. E-mail: zdenek.joska@unob.cz

\begin{abstract}
Austenitic stainless steels are common spread in many industries. Plasma nitriding is one of the few technologies that allows surface modification of austenitic stainless steels. In this study, a plasma nitriding method to form a hard surface layer at two different austenitic steels AISI 302 and AISI 316L. The surface morphology, chemical composition and mechanical properties of the formed layers were described and the results were compared with each other. The formed nitrided layers on both steels created a uniform multi-phase layer which was characterized by high hardness and very good abrasion resistance.
\end{abstract}

Keywords: austenitic stainless steel, plasma nitriding, microhardness, metallography

\section{Introduction}

Austenitic stainless steels are widely used in many industries due to their excellent corrosion resistance, ductility and high temperature strength. Unfortunately, their low hardness and poor abrasion resistance limit their further possible use. Plasma nitriding is one of the few possible ways to increase the surface hardness of these steels $[1,2,3]$. By applying plasma nitriding at lower temperatures of about $400^{\circ} \mathrm{C}$, a layer of interstitial supersaturated austenite, referred to as the $\mathrm{S}$ phase, is formed which excels in high hardness, good abrasion resistance and corrosion resistance but low layer thickness $[2,3,4,5,6]$. At temperatures above $450^{\circ} \mathrm{C}$, a multiphase "dark" layer of iron and chromium nitride precipitates forms that cause high layer hardness but partially reduce the corrosion resistance of the steel and change the corrosion mechanism [6]. However, these hard layers are very often used as a intermediate layer for thin, very hard coatings applied by the PVD method $[7,8,9,10]$. The paper deals with the evaluation of plasma nitrided steels AISI 302 and AISI 316L, which were nitrided under various conditions.

Tab. 1 Chemical composition of stainless steels

Chemical composition (\%)

\begin{tabular}{|l|l|l|l|l|l|l|l|l|}
\hline & $\mathrm{C}$ & $\mathrm{Mn}$ & $\mathrm{Cr}$ & $\mathrm{Ni}$ & $\mathrm{Si}$ & $\mathrm{P}$ & $\mathrm{S}$ & $\mathrm{Mo}$ \\
\hline AISI 302 & $\leq 0.12$ & $\leq 2.00$ & $17-19$ & $8-10$ & $\leq 1.00$ & $\leq 0.045$ & $\leq 0.03$ & - \\
\hline GDOES/Bulk & 0.045 & 1.78 & 18.7 & 8.75 & 0.48 & 0.030 & 0.001 & - \\
\hline AISI 316 L & $\leq 0.03$ & $\leq 2.00$ & $16.5-18.5$ & $10-13$ & $\leq 1.00$ & $\leq 0.045$ & $\leq 0.03$ & $2.0-2.5$ \\
\hline GDOES/Bulk & 0.03 & 1.50 & 16.97 & 10.70 & 0.31 & 0.030 & 0.026 & 2.18 \\
\hline
\end{tabular}

Tab. 2 Parameters of plasma nitriding process

\begin{tabular}{|l|l|l|l|l|}
\hline & \multicolumn{2}{|c|}{ Group 1 } & \multicolumn{2}{c|}{ Group 2 } \\
\hline & Cleaning & Nitriding & Cleaning & Nitriding \\
\hline Temperature $\left[{ }^{\circ} \mathrm{C}\right]$ & 520 & 490 & 500 & 520 \\
\hline Duration [hours] & 0,5 & 30 & 4 & 18 \\
\hline $\begin{array}{l}\text { Gas flow } \\
\text { H2/N2/Ar [1.min-1] }\end{array}$ & $20 / 2$ & $24 / 8$ & $20 / 3.2 / 1,6$ & $25 / 10 / 0$ \\
\hline Pressure [Pa] & 80 & 320 & 80 & 320 \\
\hline Bias [V] & 800 & 520 & 700 & 520 \\
\hline Pulse lenght [ $\mu \mathrm{s}]$ & 100 & 100 & 100 & 100 \\
\hline
\end{tabular}

\section{Experimental procedure}

Two groups of samples were prepared for the experiment. The AISI 302 steel samples were 50 x $30 \mathrm{~mm}$ and $2 \mathrm{~mm}$ thick in the unprocessed state, and the $316 \mathrm{~L}$ steel had a $30 \mathrm{~mm}$ diameter and $7 \mathrm{~mm}$ thickness. The surface of the samples was ground and polished to a mirror finish and cleaned in an ultrasonic bath. Verification of the chemical composition was performed by means of the GDOES / Bulk method on the LECO SA 2000 device. The measured values of the chemical composition are given in Tab. 1. Subsequently, the samples were nitrided in PN 60/60 by Rübig at different temperatures and times, see Tab. 2. Sputter cleaning was conducted in an $\mathrm{Ar}-$ $\mathrm{H}_{2}$ atmosphere prior to plasma nitriding with a pulsed-DC glow discharge. All samples were cooled after plasma nitriding in vacuum. After nitriding, samples were cut and metallographic analysis performed on an Olympus Lext 3100 confocal microscope. Further, the microhardness course was measured on the LECO AMH 47 automatic microhardness tester. The Vickers method was selected, the load was 50 grams. The course of microhardness was measured at 5 locations on each sample. 
A universal hardness tester Zwick ZHU 2.5 was used to measure the universal hardness of nitrided layers. The material characteristics of Fig. 1 were determined using software (TestXpert ${ }^{\circledR}$, Zwick). According to ČSN EN ISO 14577-1 [11, 12]. The universal hardness was mea- sured on the surface of samples using an instrumented indentation test, see Fig. 1, at a load of 194 N, a dwell time at load of $12 \mathrm{~s}$. Five measurements were performed on each sample. The resulting values were calculated arithmetic mean.

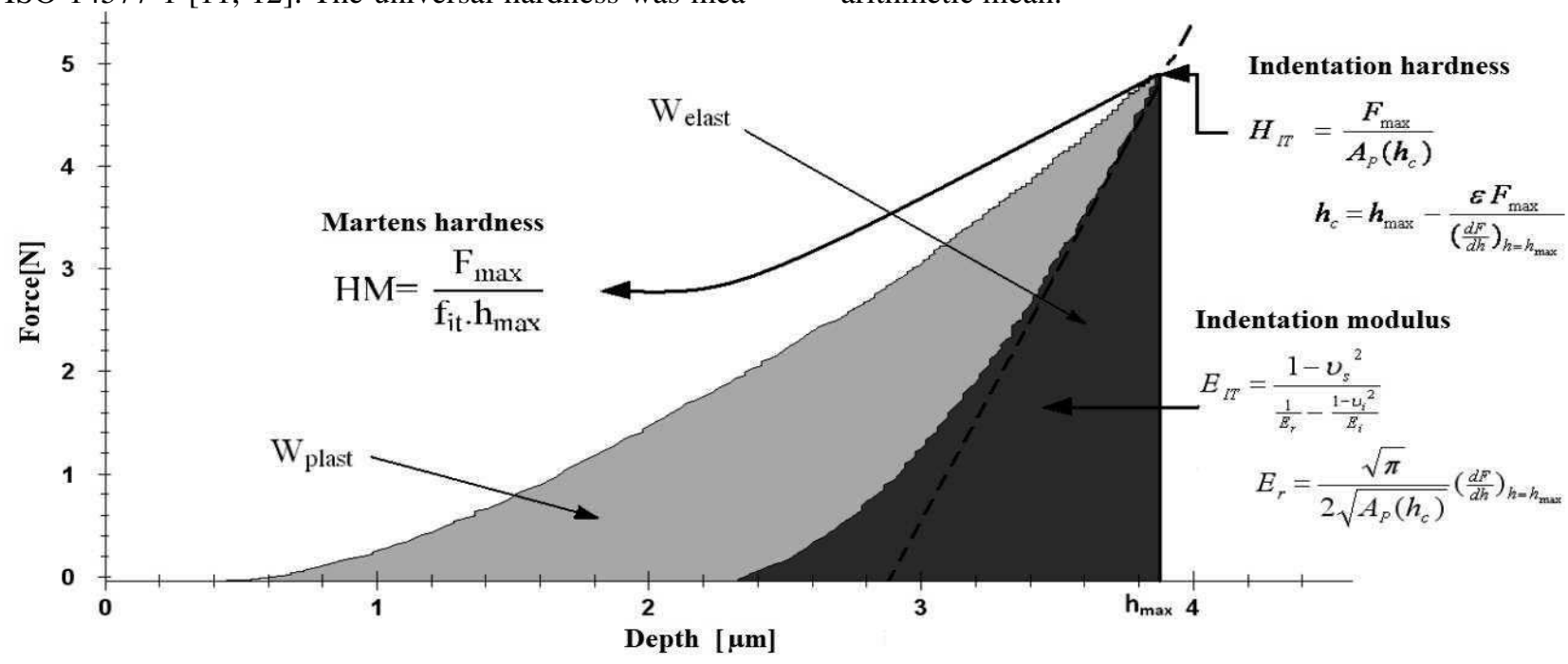

Fig. 1 Load-displacement curve

\section{Results}

From the metallographic images (Fig. 2) plasma nitrided samples is seen to achieve different thicknesses of nitrided layers. For specimens that were nitrided at 490 ${ }^{\circ} \mathrm{C}$ for $30 \mathrm{~h}$, AISI 302 formed a solid, sharply defined layer of $70 \mu \mathrm{m}$ thickness, while for $316 \mathrm{~L}$ steel a layer of $45 \mu \mathrm{m}$ thickness showed no trace of nitrided layer complete diffusion of nitrogen and the layer has an irregular shape at the bottom. Nitriding at $520{ }^{\circ} \mathrm{C}$ for 18 hours produced uniformly diffuse layers in both steels. The thickness of the layers was $38 \mu \mathrm{m}$ for AISI 302 and $60 \mu \mathrm{m}$ for AISI 316L.

The results of the microhardness measurement from the cross section (Fig. 3) confirmed the results obtained from metallographic images. A very sharp transition between the base material and the nitrided layer was measured for all samples. The thicknesses of the nitrided layers corresponded in all cases to those measured from metallographic images. The hardness of the nitrided layers was

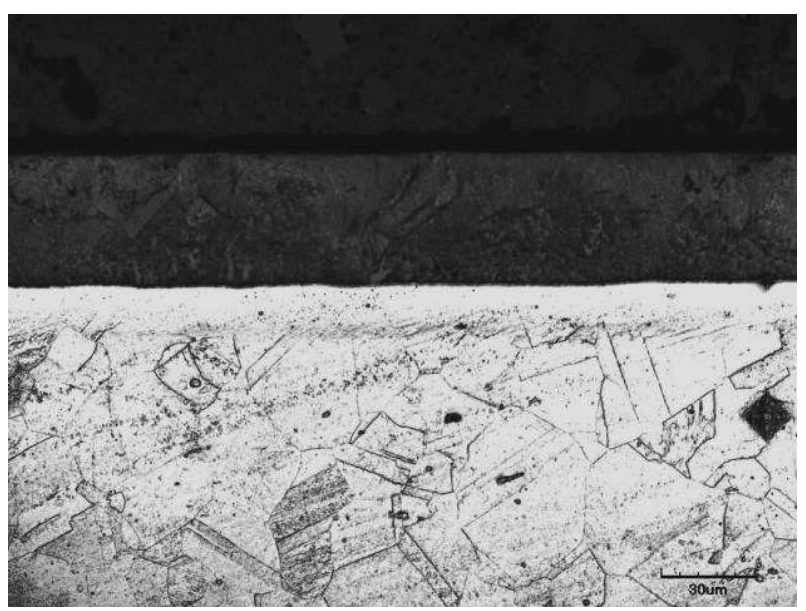

AISI 302 nitrided $520^{\circ} \mathrm{C} 18 \mathrm{~h}$ (etched aqua regia)

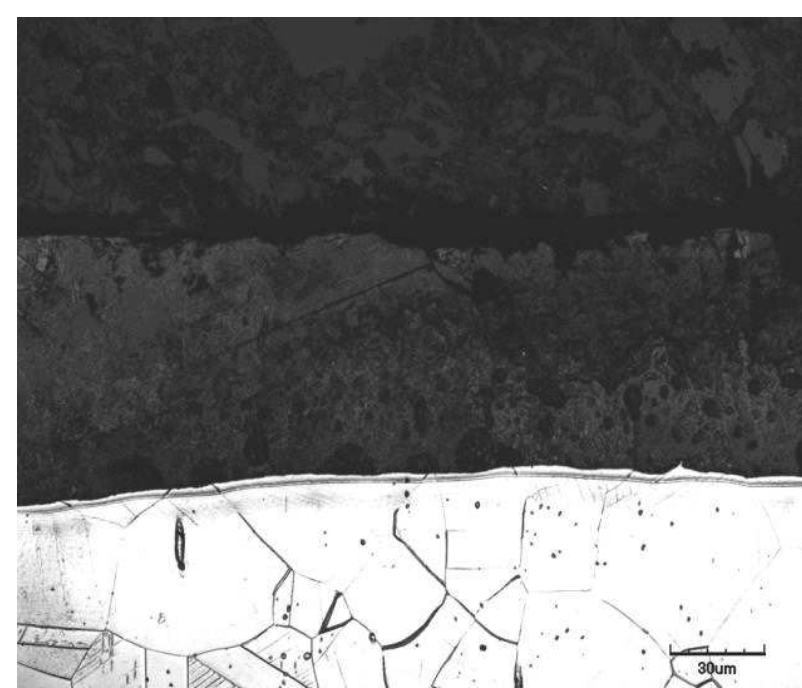

AISI 316 L nitrided $520^{\circ} \mathrm{C} 18 \mathrm{~h}$ (etched aqua regia)

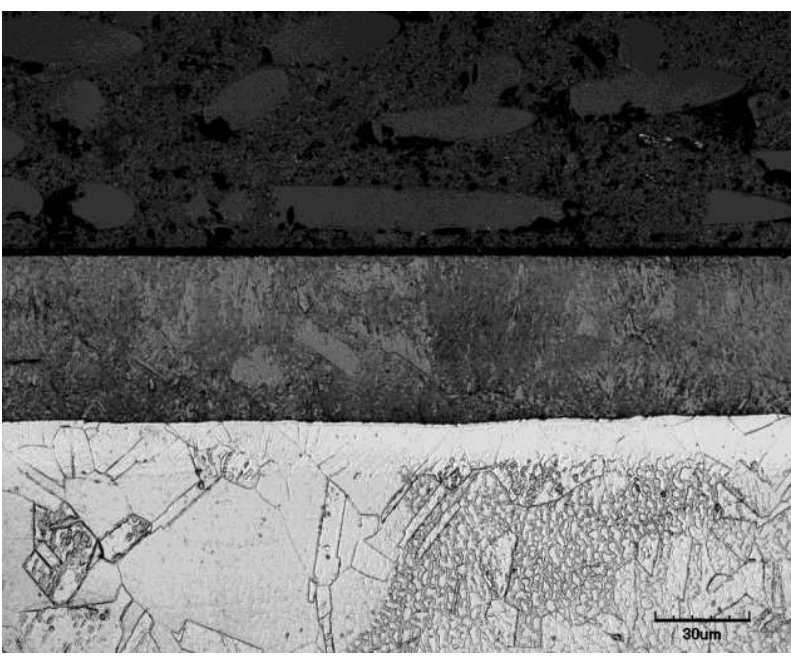

AISI 302 nitrided $490^{\circ} \mathrm{C} 30 \mathrm{~h}$ (etched aqua regia) 


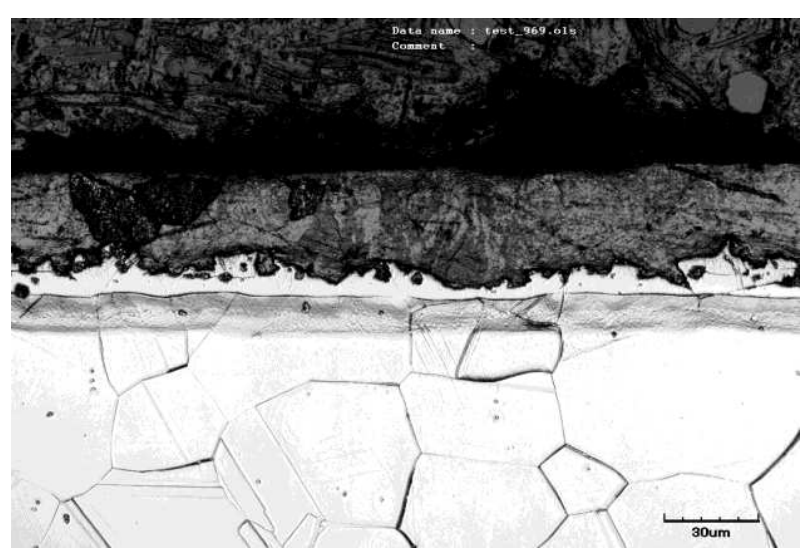

AISI 316 L nitrided $490^{\circ} \mathrm{C} 30 \mathrm{~h}$ (etched aqua regia)

Fig. 2 Cross section of nitrided stainless steel

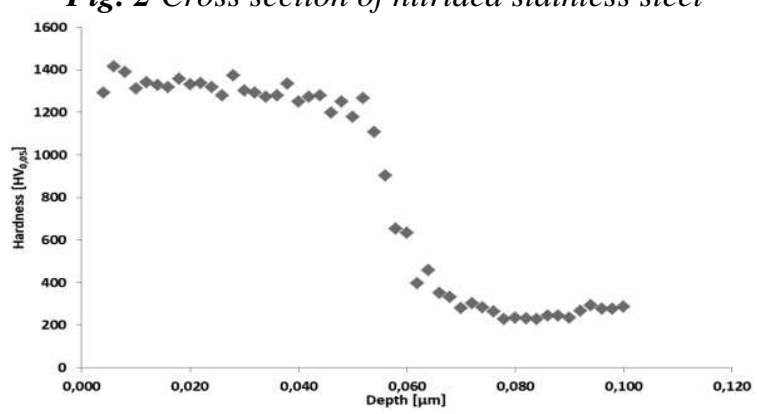

AISI 316 L nitrided $490^{\circ} \mathrm{C} 30 \mathrm{~h}$

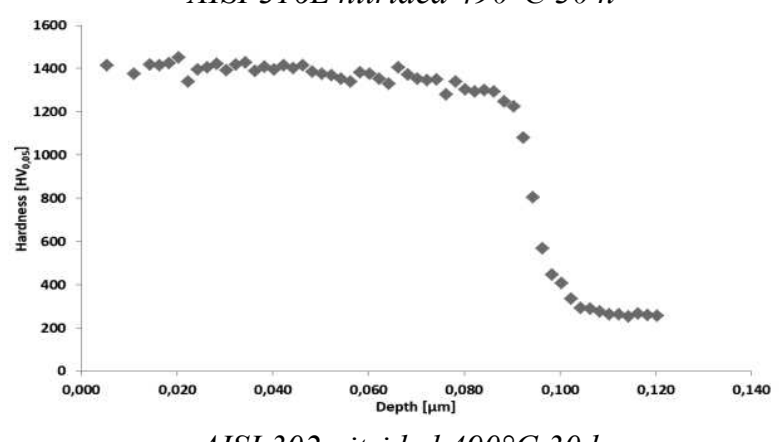

AISI 302 nitrided $490^{\circ} \mathrm{C} 30 \mathrm{~h}$

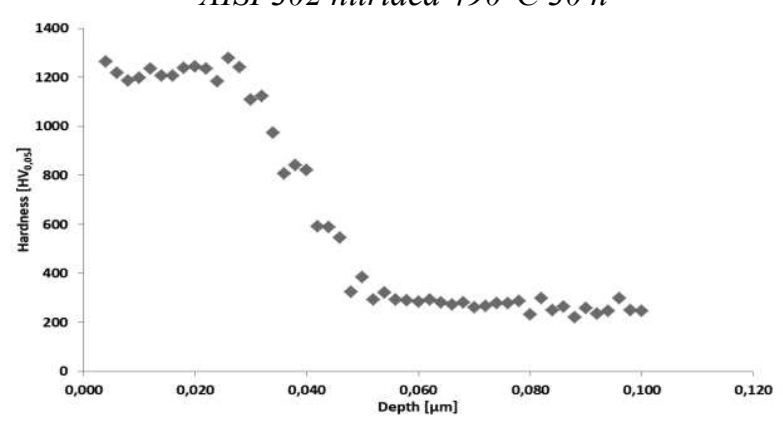

AISI $316 \mathrm{~L}$ nitrided $520^{\circ} \mathrm{C} 18 \mathrm{~h}$

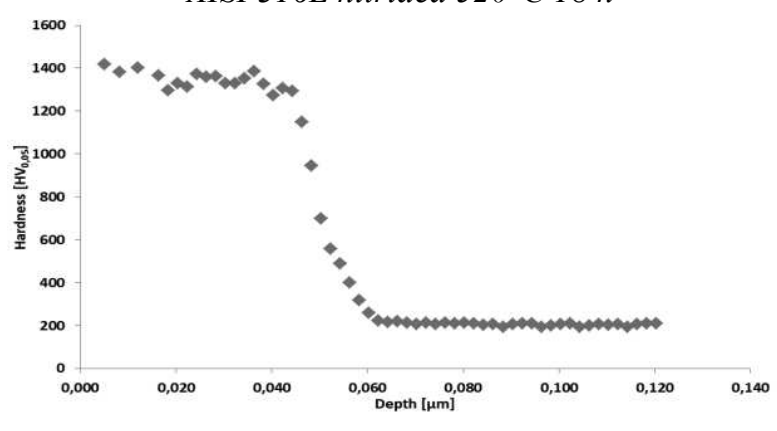

AISI 302 nitrided $520^{\circ} \mathrm{C} 18 \mathrm{~h}$

Fig. 3 Microhardness measurement
The hardness of the nitrided layers was approximately the same $1400 \mathrm{HV}_{0.05}$ for both stainless steels. On the samples, the course of universal hardness was measured from the surface in dependence on the indentation depth, the picture shows that at nitriding $520{ }^{\circ} \mathrm{C}$ the universal hardness on the surface of both samples reached very similar values 7500 N.mm ${ }^{-2}$ for AISI $316 \mathrm{~L}$ and 7000 $\mathrm{N} . \mathrm{mm}^{-2}$ for AISI 302 steel and the universal hardness waveforms gradually decreased to around $200 \mathrm{~N} . \mathrm{mm}^{-2}$, higher universal hardness values were achieved for AISI $316 \mathrm{~L}$ due to its greater depth. For nitriding at $490{ }^{\circ} \mathrm{C}$, the waveforms were different AISI $316 \mathrm{~L}$ steel had a surface hardness of only $4500 \mathrm{~N} . \mathrm{mm}^{-2}$. For AISI 302 steel, the universal hardness on the surface reached $7000 \mathrm{~N} . \mathrm{mm}^{-2}$.

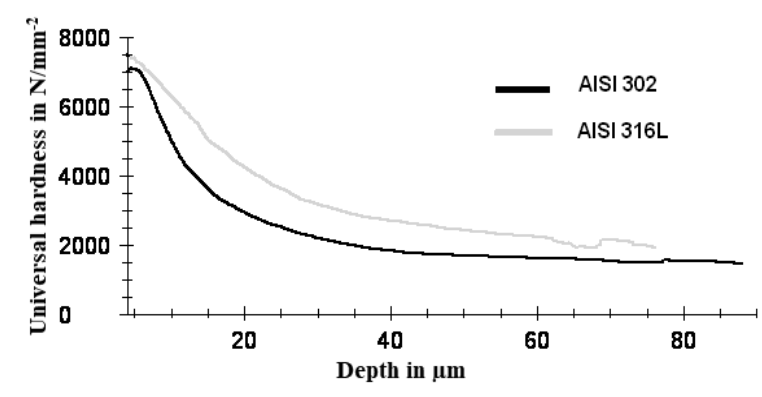

Samples nitrided $520^{\circ} \mathrm{C}$ for $18 \mathrm{~h}$

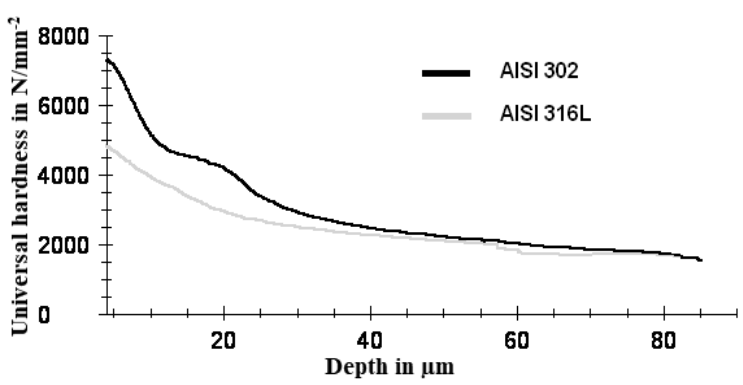

Samples nitrided $490^{\circ} \mathrm{C}$ for $30 \mathrm{~h}$

Fig. 4 Coarse of universal hardness of nitrided samples

In the nitrided layer formed at $490^{\circ} \mathrm{C}$ for 30 hours, a significant change in the course of the universal hardness was recorded at a depth of 10 microns. In the optical observation of the puncture after the indentation test, it was found that the nitrided layer showed a breakage and fall of the layer, which was confirmed by the course of the indentation curve (see Fig. 5).

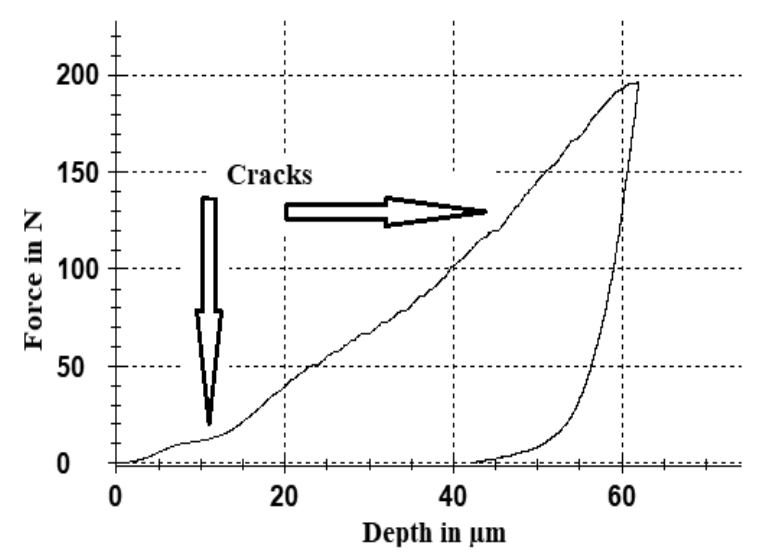




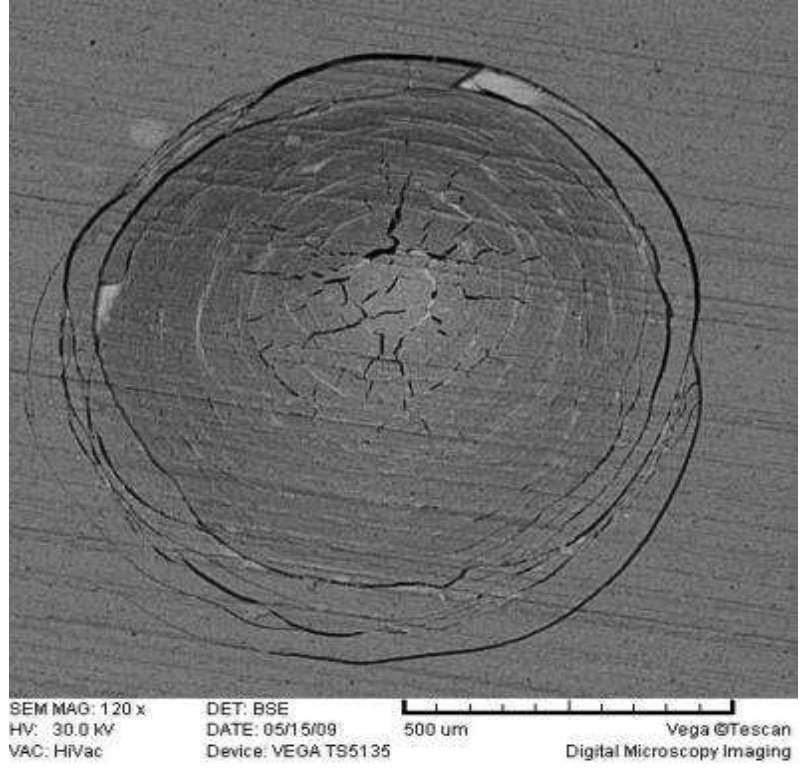

Fig. 5 Cracking of nitrided layer

\section{Conclusion}

The aim of the experiment was to evaluate the influence of different nitriding conditions on the properties of the nitrided layer in austenitic stainless steels AISI 302 and AISI 316L. The experiment showed that the nitrided layer of AISI 316L achieves lower nitrided layer depth values and its universal hardness is slightly lower than that of AISI 302. This is most likely due to the different molybdenum content, which has somewhat retarded nitride diffusion and nitrided layer formation. At nitriding at $490^{\circ} \mathrm{C}$ for 30 hours, for $316 \mathrm{~L}$ steel, nitrides precipitated along the boundary and in the center of the grains at the bottom of the layer. Plasma nitriding at $520^{\circ} \mathrm{C}$ resulted in the formation of sharply bounded solid layers on both samples.

The experiment has shown that plasma nitriding can achieve a significant increasig of surface hardness and thus abrasion resistance of austenitic stainless steels, thereby increasing their application potential.

\section{Acknowledgement}

The present research work was supported by Specific research SV 2019. The work was supported by a Research Project for the Development of Technologies, Design of Firearms, Ammunition, Instrumentation, Engineering of Materials and Military Infrastructure "VYZBROJ (DZRO K201)” and specific research SV18-216, Heat treatment of steels and modeling of thermodynamic processes".

\section{References}

[1] HOLEMÁř, A., HRUBÝ V.(1989). Iontová nitridace v praxi. SNTL, Praha

[2] LO, K.H., SHEK, C.H., LAI, J.K.L. (2009). Recent developments in stainless steel. Materials
Science and Engineering: R: Reports., roč. 65, s. 39-104

[3] BUHAGIAR, J., LI, X., DONG, H. (2009). Formation and microstructural characterisation of $\mathrm{S}$ phase layers in Ni-freeaustenitic stainless steels by low-temperature plasma surface alloying. Surface and Coatings Technology, roč. 204, č. 3, s. 330335

[4] KADLEC, J; DVOŘÁK, M. (2008). Duplex surface treatment of stainless steel X12CrNi 188 . Strength of Materials, roč. 40, č. 1, s. 118-121.

[5] CHENG, Z., LI, X., DONG, H., Bell, T. (2005). Low temperature plasma nitrocarburising of AISI 316 austenitic stainless steel. Surface and Coatings Technology, roč. 191, č. 2-3, s. 195-200

[6] POKORNÝ, Z., HRUBÝ, V.,(2011). Plasma nitriding of deep narrow cavities. Key Engineering of Materials, roč. 465 , s. 267-270

[7] JOSKA, Z., et al. (2010). Mechanical Properties of Duplex System: ZrN Coating on Plasma Nitrided Stainless Steel. Chemicke listy, roč. 104, č. 15, s. 322-325

[8] HERAS, E., et al.(2008). Duplex surface treatment of an AISI 316L stainless steel; microstructure and tribological behaviour. Surface and Coatings Technology, roč. 202, č. 13, s. 2945-2954

[9] JELINEK, M., et al.(2006). KrF laser deposition combined with magnetron sputtering to grow titanium-carbide layers. Thin Solid Films, roč. 506, s. 101-105

[10] JOSKA, Z., et al. (2011). Characteristics of Duplex Coating on Austenitic Stainless Steel. Key Engineering Materials, 2011, vol. 465, no. 1, p. 255-258.

[11] ČSN EN ISO 14577-1 Kovové materiály - Instrumentovaná vnikací zkouška stanovení tvrdosti a materiálových parametrů - Č́st 1: Zkušební metoda

[12] OLIVER, W., Pharr, G. (1992). An improved technique for determining hardness and elastic modulus using load and displacement sensing indentation experiments. Journal of Materials Research,roč 7, s. 1564-1583

[13] POKORNÝ, Z., STUDENÝ, Z., POSPÍCHAL, M., HRUBÝ, V., JOSKA, Z. (2015). Characteristics of plasma nitrided layers. Manufacturing Technology, Vol. 15, No. 3, pp. 403-409. ISSN 1213-2489.

[14] STUDENÝ, Z. (2015). Analysis of the influence of initiating inclusions on fatigue life in plasma nitrided steels. Manufacturing Technology, Vol. 15, No. 1, pp. 99-105. ISSN 1213-2489. 